\title{
$355.31: 355.54$
}

. . естюк, . . орошев

ввівський інститут ухопутнихвійськ, ввів

озгляд ється процес підготовки ф хівців опер торського типу діяльності для бройних ил кр їни. основі н лізу процесу підготовки н відник $m$ нк -64 н ведено результ ти оцінюв ння дин міки

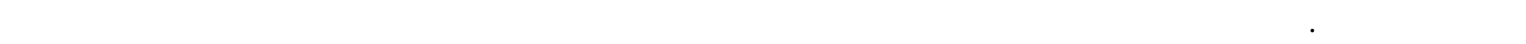
н прямки підготовки ф хівців опер торського типу діяльності.

лючові слов : трен жерні з соби, ф хівці опер торського типу діяльності.

\section{сту п}

ост новк проблеми. суч сних умов $\mathrm{x}$, коли особливо гостро стоїть пит ння з безпечення необхідного фін нсув ння бойової підготовки бройних ил ( ) кр їни, в пр ктиці бойового н вЧ ння все більш широке $з$ стосув ння зн ходять н вч льно-тренув льні з соби ( ), що з безпечують підвищення якості бойової підготовки ч стин і підрозділів, скорочення ч су н освоєння бойової техніки, економію іiї ресурсу і зниження в рійності через непр вильну експлу т цію.

езв ж ючи н високу кту льність щодо 3 безпечення військ суч сними трен жерними з соб ми, н явність їх у військ х (н вч льних з кл д х) 6 ж є бути кр щою. елик ч стин з них мор льно $з$ ст ріл бо відпр цюв л свій ресурс. т н укомплектов ності ухопутних військ ( )

кр їни н вч льно-тренув льними з соб ми ( ) нового покоління не відповід $є$ вимог м сьогодення - для потреб військ з куплено всього 6 трен жерів.

н ліз ситу ції, що скл л ся ост ннім ч сом у системі бойової підготовки військ і в н вч льновиховному процесі вищих військових н вч льних 3 кл дів, свідчить про те, що рівень використ ння зн чно відст $€$ від н логічних пок зників збройних сил провідних кр їн світу (т бл. 1) $[1,2]$.

івень використ ння трен жерних з собів у кр їни т провідних кр їн $\mathbf{x}$ світу

\begin{tabular}{|l|c|c|}
\multicolumn{1}{|c}{ кр іни т провідних кр ін х світу } \\
\hline ерж ви-члени & $\begin{array}{c}\text { ідготовк } \\
\text { мех ніків- } \\
\text { водіїв }\end{array}$ & $\begin{array}{c}\text { ідготовк } \\
\text { н відників }\end{array}$ \\
\hline кр їн & $80 \%$ & $80 \%$ \\
\hline осія & $48 \%$ & $\begin{array}{c}\text { рогр м ми не } \\
\text { визн чено через } \\
\text { відсутність відповід- } \\
\text { них трен жерів }\end{array}$ \\
\hline
\end{tabular}

уч сне озброєння т військов технік ( ) , створені н основі досягнень н уки й техніки ст., м ють високі т ктико-технічні х р ктеристики, бойов робот н них передб ч є десятки опер цій, у тому числі опер ції типу «прийняття рішення». хівці, які виконують ці опер ції, - це ф хівці опер торського типу діяльності ( ). они визн ч ють ступінь ре ліз ції бойових можливостей озброєння, отже, рівень боєзд тності й бойової готовності підрозділів і ч стин

кр їни. им обумовлюється в жливість підготовки для кр їни. уть проблеми поляг $є$ у тому, що н явн н вч льно-м тері льн 6 з не в повному обсязі відповід є вимог м підготовки високо-Кв ліфіков них для кр їни.

ільшість військово-облікових спеці льностей кр їни (пон д 70\%) н лежить до опер торського типу діяльності. е ком ндири т н відники т нків, бойових м шин піхоти й с мохідних ртилерійських систем; ком ндири, н відники й опер тори зенітних р кетних (г рм тно p кетних) комплексів; н ві дники протит нкових керов них комплексів; опер тори р діолок ційних ст нцій, систем зв'язку, з собів і систем втом тизов ного упр вління зброєю т ін.

процесі бойового з стосув ння озброєння т військової техніки військовослужбовці виступ ють як опер тори в різних систем х упр вління.

йбільш $\mathrm{x}$ р ктерними 3 них $є$ системи упр вління рухомими об' єКт ми, з соб ми збир ння інформ ції (спостереження 3 обст новкою), енергетичними уст новк ми, циклічними процес ми т системи упр вління диспетчерського типу [3].

тже, пит ння використ ння трен жерних 3 собів і підготовки н їх 6 зі висококв ліфіков них ф хівців є дуже кту льним сьогодні, необхідність дослідження цих пит нь не виклик є сумнівів.

н ліз ост нніх досліджень і публік цій. Я проблем розгляд л ся в $[1,2,4,7]$, ле в цих пр цях

(C) . естюк, . . орошев 
основн ув г приділял ся окремим пит нням побудови н вч льної м тері льно-технічної б зи для бойової підготовки кр їни, і пр ктично не розгляд лися пит ння формув ння у стійких н вичок бойової роботи. кож не оцінюв лися процеси н буття т втр ти н вичок бойової роботи.

н шу думку, т кий підхід не зовсім д є змогу визн чити періодичність т інтенсивність підготовки для інших військово-облікових спеці льностей, хоч , використовуючи н пр цюв ння попередників, іiі можн спрогнозув ти.

етою ст тті $\epsilon$ :

- оцінк можливого рівня підготовки

з д ному ч сі підготовки;

- прогнозув ння ч су, який необхідний для підготовки опер тор до з д ного рівня;

- визн чення допустимих перерв між з няттями, які

з безпечують підтрим ння н вичок н рівні, що вим г ється;

- н д ння пр ктичних рекоменд цій щодо періодичності проведення з нять н для мех нізов них (т нкових) підрозділів.

\section{сновний м тері л}

вч ння н сприяє підвищенню т інтенсифік ції процесу н вч ння і вироблення у тих, Хто н вч ється, у більш стислі терміни, н вичок 3 ефективного з стосув ння зброї (озброєння) у бою.

$$
\text { стосув ння для підготовкИ }
$$

вирішує н ступні пит ння:

- роздрібнення скл дних елементів н прості дії для ï послідовного з своєння 3 поступовим ускл дненням умов тренув ння;

- нег йн об'єктивн оцінк якості викон ння прийомів, фікс ції допущених помилок, одноч сного пок зу вірних дій і повторення впр в и до безпомилкового її викон ння;

- більш продуктивне використ ння н вч льного ч су з р хунок скорочення переїздів н н вч льні поля і відриву особового скл ду для підготовки м тері льної ч стини і м ршрутів до з нять і н с тупного відновлення н вч льно-м тері льної б зи;

- з безпечення безпеки н вч ння, що дозволяє розширити с мостійність того, хто н вч ється, в його діях i рішеннях у критичних $\mathrm{i}$ в рійних ситу ціях, що не допуск ється н шт тних бойових м шин $\mathrm{x}$;

- скорочення витр ти ресурсів н відпр цюв ння техніки водіння, удоскон лення н вичок у діях при озброєнні, зменшення н пруженості експлу т ції бойової техніки, скорочення кількості ушкоджень (поломок) і відповідно потреби в 3 п сних ч стин $\mathrm{x}$, п льного т зм щув льних м тері лів, зниження 3 в нт ження підрозділів для обслуговув ння і відновлення;
- створення умов для м сової підготовки й перепідготовки спеці лістів н нові і перспективні м шини.

ідготовк являє собою систему н вч льних з ходів, шо проводяться 3 метою підвищення теоретичних i удоскон лення пр ктичних н вичок для викон ння ними функціон льних обов'язків у бою.

ри орг ніз ції системи підготовки

виник є необхідність у вирішенні ряду пр ктичних 3 вд нь, які пов'яз ні 3 пл нув нням i прогнозув нням iï результ тів. о т ких 3 вд нь доцільно віднести:

- оцінку можливого рівня підготовки при з д ному ч сі підготовки;

- прогнозув ння ч су, який необхідний для підготовки до з д ного рівня;

- визн чення допустимих перерв між з няттями, які з безпечують підтрим ння н вичок н необхідному рівні.

ля вирішення цих з вд нь необхідно м ти м тем тичні моделі (оцінки т прогнозув ння) н вченості. ідомо дв способи отрим ння т ких моделей:

1. ксперимент льний, який поляг $€$ в проксим ції експеримент льних д них, отрим них у результ ті (оцінки рівня підготовки) н лізу різних процесів підготовки, н літично ю функцією.

2. трим ння н літичної 3 лежності теоретичним шляхом н основі будь-якої відомої теорії, як з довольняє психологічне т м тем тичне уявлення процесу підготовки опер торів.

скільки сьогодні підготовк опер торів (з лежить від н явності тренув льних з собів, їх якості, декв тності ре льним умов м) пр ктично згорнут, то вирішити з вд ння експеримент льним методом пр ктично неможливо. ому розглянемо другий спосіб отрим ння т ких д них.

рийнято вв ж ти, що той, хто н вч ється, діє 3 м ксим льною ефективністю, якщо він буде без помилок і в мінім льно можливий ч с виконув ти свої функціон льні обов'язки в бою, при цьому можливості , якими він володіє, ре лізуються повністю і можн вести мову про досягнення їх потенційної ефективності.

роцес н вч ння будемо розгляд ти як процес впливу н нього викл д цького скл ду шляхом перед чі йому інформ ції і розвитку н іiї основі необхідних вмінь і н вичок. міру н копичення зн нь, умінь і н вичок опер тор переходить з одного рівня н інший.

иходячи 3 цього, для м тем тичної форм ліз ції процесу н вч ння доцільно скорист тись м тем тичним п р том, який розроблений в [1]. 
рогнозув ння ч су ${ }_{n}$, який необхідний для підготовки опер тор до з д ного рівня $Q_{\text {зад}}$, можн здійснюв ти з допомогою н ступного вир зу:

$$
{ }_{n}={ }_{0} \ln \left[\frac{Q_{\max }-Q_{0}}{Q_{\max }-Q_{3} \partial}\right],
$$

де $\quad$ - коефіцієнт, який х р ктеризує спроможність опер тор до н вченості в одиницях ч су; $Q_{\max }-$ м ксим льний рівень підготовки опер тор ; $Q_{0}-$ поч тковий рівень підготовки опер тор ; $Q_{\text {зад }}-$ 3 д ний рівень підготовки опер тор .

вир зі (1) не вр хов н скл дність функціон льних обов'язків, яким н вч ється опер тор.

ля ф хівців мех нізов них (т нкових) військ, де необхідно вр ховув ти скл дність зр зК який вони вивч ють, зн чення коефіцієнтів скл дності функціон льних обов'язків для деяких пос д мех нізов них і т нкових військ отрим ні методом експертного опитув ння (т бл. 2).

блиия 2

н чення коефіцієнтів скл дності функціон льних обов'язків для деяких пос д мех нізов них і т нкових військ

\begin{tabular}{|c|c|r|r|r|r|}
\hline \multirow{2}{*}{ ід військ } & \multicolumn{5}{|c|}{ н чення коефіцієнтів скл дності } \\
\cline { 1 - 6 } & 0,3 & 0,4 & 0,5 & 0,6 & \multicolumn{1}{c|}{0,8} \\
\hline $\begin{array}{c}\text { ех нізов ні } \\
\text { військ }\end{array}$ & & -60 & -70 & -80 & \\
\hline $\begin{array}{c}\text { нкові } \\
\text { військ }\end{array}$ & -64 & & -64 & & -84 \\
\hline
\end{tabular}

сновним ф ктором, який визн ч $є$ ч с підготовки для досягнення ним необхідного рівня підготовки, є скл дність зр зку , який вивч ється, спроможності опер тор до н вч ння (спроможності опер тор з своїти функціон льні обов'язки у визн чений термін) т перерви в роботі.

я спроможність, у свою чергу, з лежить від якості н вч льного процесу, кв ліфік ції викл д цького скл ду і ст ну н вч льної м тері льно-технічної б зи, т кож від його особистих якостей: мор льно-психологічних, мотив ції до військово-професійного н вч ння, дисциплінов ності тощо.

івень підготовки відмінно підготовлених опе p торів почин є знижув тись вже після триденної перерви у підготовці, у менш підготовлених - через 1-2 дні.

видкість зниження вмінь і н вичок тим більш , чим нижчий рівень підготовки опер тор . освід пок зує, що н йбільш «чутливими» до перерви у н вЧ нні є вміння т н вички скл дної діяльності, як обумовлюється скл дністю

ри перерві в 3 няттях більш ніж 20 днів якість підготовки н віть відмінно підготовлених ф хівців знижується н 50\%, після дво-тримісячної перерви скл д є всього 30 - $35 \%$ поч ткового рівня.

ри викон нні з вд нь середньої скл дності після тримісячної перерви рівень підготовки скл д $є$ приблизно 50\% поч ткового рівня.

p ктер з був ння лгоритмів вирішення скл дних з вд нь н ведений у т бл. 3.

основі н ведених вище розр хунків доцільно вст новити допустимі перерви в 3 няттях 3 підготовки опер торів т необхідну періодичність проведення цих 3 нять, при яких з безпечується підтрим ння вмінь і н вичок 3 військово-обліковою спеці льністю н необхідному рівні.

р ктер з був ння лгоритмів вирішення скЛ дних 3 вд нь

\begin{tabular}{|c|c|}
\hline $\begin{array}{c}\text { ермін перерви } \\
\text { в з няттях }\end{array}$ & $\begin{array}{c}\text { ркер з був ння лгоритмів } \\
\text { рішення з вд нь }\end{array}$ \\
\hline о 5 днів & $\begin{array}{c}\text { був ння незн чне (м є місце чітке } \\
\text { зн ння лгоритмів рішення з вд ння) }\end{array}$ \\
\hline о 20 днів & $\begin{array}{c}\text { ри викон нні лгоритму пропуск ється } \\
\text { до 10\% опер цій }\end{array}$ \\
\hline о 30 днів & $\begin{array}{c}\text { ропуск ється до 20\% опер цій, } \\
\text { втом тизм в діях порушується }\end{array}$ \\
\hline ільше 30 днів & $\begin{array}{c}\text { ішення скл дних з вд нь без дод т - } \\
\text { кової підготовки пр ктично неможливе }\end{array}$ \\
\hline
\end{tabular}

3 результ тів досліджень видно, що м ксим льно припустимий термін перерв між 3 няттями не повинен перевищув ти 15 - 30 днів. ому виведені н рівень ст ціон рної н вченості опер тори повинні підтримув ти піi шляхом періодичних з нять.

вич йно, $з$ няття н трен жер х не 3 мінять ре льних 3 нять н техніці, тому пропонується 3 стосовув ти комбінов ний в рі нт підготовки опер торів.

н шу думку, періодичність 3 нять н повинн м ти зн чення, н ведені в т бл. 4.

блиця 4

\begin{tabular}{|c|c|c|c|}
\hline \multicolumn{4}{|c|}{ шт тному } \\
\hline $\begin{array}{l}\text { еріодичність } \\
\text { тренув нь }\end{array}$ & еобхідні норми витр т & $\begin{array}{l}\text { еріодичність } \\
\text { тренув нь } \\
\end{array}$ & орми витр т н місяць \\
\hline $\begin{array}{c}2-3 \text { год. н одне } \\
\text { тренув ння } \\
1 \text { тренув ння н } \\
\text { тиждень } \\
4 \text { тренув ння н } \\
\text { місяць }\end{array}$ & $\begin{array}{l}\text { кількість мотогод. ре льної роботи техніки -24; } \\
\text { кількість пострілів вкл дним стволом -9; } \\
\text { кількість пр ктичних пострілів із т нкової } \\
\text { г рм ти -6 (з цикл н вч ння); } \\
\text { кількість пострілів з г рм ти },-124 ; \\
\text { кількість пострілів з кулемет }-165 ; \\
\text { кількість пусків }-3\end{array}$ & \begin{tabular}{|c|}
$2-3$ год. н \\
одне \\
тренув ння \\
2 тренув ння \\
н тиждень \\
8 тренув нь н \\
місяць \\
\end{tabular} & $\begin{array}{l}\text { кількість год. роботи н трен жері -9-12 } \\
\text { кількість електронних пострілів: } \\
\text { н відник т нк -60-80; } \\
\text { ком ндир т нк -60-80; } \\
\text { н відник } \\
\text { ком ндир відділення ( })-300 ; \\
\text { опер тор } \\
\end{array}$ \\
\hline
\end{tabular}

(C) . естюк, . . орошев 
цінк рівня н вченості ф хівців і підрозділів мех нізов них (т нкових) підрозділів при різних в рі нт х бойової підготовки

\begin{tabular}{|c|c|c|c|c|}
\hline \multirow{3}{*}{$\begin{array}{c}\text { т пи } \\
\text { підготовки }\end{array}$} & \multicolumn{4}{|c|}{ рі нти підготовки } \\
\hline & \multicolumn{2}{|c|}{$\mathrm{p}$ диційний } & \multicolumn{2}{|r|}{ омбінов ний } \\
\hline & $\begin{array}{c}\text { с } \\
\text { Н Вч ННЯ, (міс.) }\end{array}$ & івень н вченості & $\begin{array}{c}\text { с } \\
\text { Н Вч ННЯ, (міс.) } \\
\end{array}$ & $\begin{array}{c}\text { івень } \\
\text { Н вченості }\end{array}$ \\
\hline $\begin{array}{c}\text { ндивіду льн } \\
\text { підготовк }\end{array}$ & 4 & 3 довільний & 2 & добрий і відмінний \\
\hline скл ді екіп жу & 3 & $\begin{array}{l}3 \text { довільний і добрий (до } \\
\text { кінця періоду н вч ння) }\end{array}$ & $1,5-2$ & $\begin{array}{c}\text { добрий і відмінний } \\
\text { (до кінця першого місяця н вч ння) }\end{array}$ \\
\hline скл ді підрозділу & 3 & \begin{tabular}{|l}
3 довільний і добрий (до \\
кінця періоду н вч ння)
\end{tabular} & 2 & $\begin{array}{c}\text { добрий і відмінний } \\
\text { (до кінця першого місяця н вч ння) }\end{array}$ \\
\hline $\begin{array}{l}\text { н чення рівня } \\
\text { н вченості }\end{array}$ & \multicolumn{2}{|c|}{$\underline{0,55}-0,62$} & \multicolumn{2}{|r|}{$0,75-0,9$} \\
\hline
\end{tabular}

ким чином, у процесі підготовки повинн бути викон н н ступн кількість стрільб: 3 тиждень - 15-20; $з$ місяць - 60-80; $з$ півроку - 300-400; 3 рік $-600-800$.

К пок з ли розр хунки, це д сть можливість підтримув ти вміння т н вички опер торів не нижче, ніж н оцінку «добре».

ведені вище д ні д ють змогу оцінити рівень н вченості ф хівців, порівнявши дв методи підготовки: тр диційний (тільки н шт тному озброєнні) і комбінов ний (поєдн ння підготовки н комп'ютерних н півн тур льних трен жер х 3 підготовкою н шт тному озброєнні). езульт ти проведених розр хунків предст влені в т бл. 5 .

\section{Иснов К И}

ким чином, 3 пропонов ні рекоменд ції д ють змогу визн чити оцінку можливого рівня підготовки при з д ному ч сі підготовки, прогнозув ти ч с, необхідний для підготовки до з д ного рівня, визн чити допустимі перерви між 3 няттями, які з безпечують підтрим ння н вичок н рівні, що вим г ється.

ерспектив ми под льших досліджень у цьому н прямку можуть бути удоскон лення процесу підготовки і методик н вч ння $\mathrm{H}$. втори сподів ються, що їх думк 3 цік вить як н уковців, т к i, що особливо в жливо, пос дових осіб, які безпосередньо з йм ються підготовкою н всіх рівнях.

\section{писок літер тури}

1. твієвський . . етодичний підхід до обгрунтув ння х р ктеристик трен жсних з собів $i$ систем / . . твієвський, . . ер сименко, ебл нін // ук і оборон . - 2005. - №1. - . 9-12.

2. твієвський . . роблеми підготовки ф хівців опер торського типу діяльності для бройних ил $к р$ їни / . . твієвський, . . ер сименко, . . ебл нін // ук іоборон . - 2004. - №4. - . 14-17.

3. $\kappa_{3} \quad \kappa р$ їни №36 від 23.02.2002 p. " ро вдоскон лення бойової підготовки $i$ ктиковогневого вишколу військ». - .. . $31 \mathrm{c.}$

4. прямки підвищення ефективності бойової підготовки ухопутних військ бройних ил кр їни в умов х ̈̈х реформув ння. уково-пр ктичний семін р. $\therefore \quad i \quad-2003 .-105 c$

5. орічник « іл книг 2007: оборонн політик кр їни». - .: ійсько, ,2008. - 95 c.

6. орічник «іл книг 2008: оборонн політик $\kappa р$ їни». - ., повіт, 2008. - 134 c.

7. усн $\kappa$. . роблеми модерніз иї $m$ створення трен жерно-модулюв них комплексів військового призн чення / . . усн к, . . евченко // ук оборон . - 2002. - №1. - . 32-39.

8. дорник. . ысш я военн я школ : проблемы /

дорник . ., обзев . ., хров . .// оенн $я$ мысль. - 1998. - №2. - . 55-65.

9. екоменд ции по учету эргономических требов ний при р зр ботке и в процессе эксплу т ции вооружения $и$ военной техники. ниг $2 . \quad$ - .. оенизд т. - 1989. - $184 c$.

10. ождение боевых м шин. - .. оенизд т. 1989. $-187 \mathrm{c}$.

11. рогр м бойової підготовки $m$ нкових підрозділів. - ..

дійшл до ред киї 22.12.2008

ецензент: доктор фізико-м тем тичних н ук, професор . . іколенко, кр їнськ держ вн к демія з лізнич ного тр нспорту, рків. 


\section{. . естюк, . . орошев}

ссм трив ется процесс подготовки специ листов опер торского тип деятельности для ооруженных ил кр ины. основе н лиз процесс подготовки н водчик $m$ нк -64 приводятся результ ты оценив ния дин мики изменения уровня обученности н водчиков с помощью тр диционной и комбиниров нной форм боевой подготовки. боснов ны н пр вления подготовки специ листов опер торского тип деятельности.

лючевые слов : трен жерные средств , специ листы опер торского тип деятельности.

\section{PROBLEMS OF TRAINING FOR SPECIALISTS OF OPERATOR'S TYPE FOR MECHANIZED AND TANK UNITS OF THE ARMY}

A. I. Bestiuk, A. I. Doroshev

The article reveals the process of preparation for specialists of operator's type. Based on the analysis of the process of training of the gun-layer of T-64 tank, are given the results of the evaluation of dynamics of the level of training of gun-layers during traditional and combined forms of training. Directions of training for specialists of the operator's type are grounded. Keywords: trainer facilities, specialists of operator's type. 